\begin{tabular}{|c|c|c|c|c|c|c|}
\hline \multirow{4}{*}{ Impact Factor: } & ISRA (India) & $=4.971$ & SIS (USA) & $=0.912$ & ICV (Poland) & $=6.630$ \\
\hline & ISI (Dubai, UAE & $=0.829$ & РИНЦ (Russia & $=0.126$ & PIF (India) & $=1.940$ \\
\hline & GIF (Australia) & $=0.564$ & ESJI (KZ) & $=8.716$ & IBI (India) & $=4.260$ \\
\hline & JIF & $=1.500$ & SJIF (Morocco & $=5.667$ & OAJI (USA) & $=0.350$ \\
\hline
\end{tabular}

\section{SOI: $1.1 /$ TAS $\quad$ DOI: $10.15863 /$ TAS \\ International Scientific Journal Theoretical \& Applied Science}

p-ISSN: 2308-4944 (print) e-ISSN: 2409-0085 (online)

Year: $2020 \quad$ Issue: 03 Volume: 83

Published: $09.03 .2020 \quad$ http://T-Science.org
QR - Issue

QR - Article
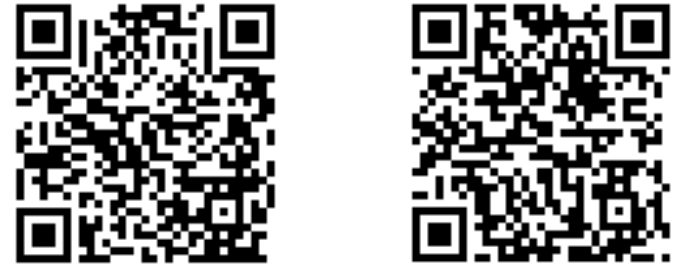

Nargiza Yusupdjanova

Tashkent Institute of Architecture and Civil Engineering Senior lecturer of the department " Economics and real estate management"

Tashkent, Uzbekistan

Inomjon Karimov

Tashkent Institute of Architecture and Civil Engineering Senior lecturer of the department " Economics and real estate management"

Tashkent, Uzbekistan

\title{
INVESTMENT PROJECTS IN THE FIELD OF CONSTRUCTION MATERIALS PRODUCTION
}

\author{
Abstract: The article presents the state of investment projects and key elements of investment management in \\ the manufacturing industry of building materials. \\ Key words: investment supply, modern methods, construction materials, investment attraction, equipment and \\ machinery, labor resources, export. \\ Language: English \\ Citation: Yusupdjanova, N., \& Karimov, I. (2020). Investment projects in the field of construction materials \\ production. ISJ Theoretical \& Applied Science, 03 (83), 18-21. \\ Soi: http://s-o-i.org/1.1/TAS-03-83-5 Doi: crossef https://dx.doi.org/10.15863/TAS.2020.03.83.5 \\ Scopus ASCC: 2213.
}

\section{Introduction}

Since the beginning of the period of independent development in the country, the head of state and the government of the Republic of Uzbekistan have been carrying out comprehensive and deeply thought-out structural reforms step by step in the implementation of socio-economic policy. The Strategy of Action on further development of the Republic of Uzbekistan, approved by the decree of the president of the Republic of Uzbekistan on February 7, 2017, sets out the fundamental goals that would be implemented in 2017-2021, as well as the means and ways to achieve these goals. Among them, as an important branch of the economy, a wide range of measures are being taken to develop the construction materials industry in terms of quality. In particular, the production of highquality, import-substituting export-oriented and competitive construction materials is being established at the manufacturers of building materials, equipped with modern techniques and technologies with the participation of foreign capital. However, the attraction of investments and the amount of investment in the sector do not fully meet the current requirements. Therefore, foreign investment in the building materials industry is one of the priorities. The strategy of action on five priority areas of development of the Republic of Uzbekistan defines important tasks on "active involvement of investments, in particular foreign investments in the sectors and regions of the economy of the country by improving the investment climate"[1].

Ensuring the effective implementation of these tasks requires the development of proposals and recommendations for increasing the effectiveness of management of attracting investments in the construction materials industry.

This dissertation research serves to a certain extent in the implementation of the tasks set out in the normative documents including, Resolution of the President of the Republic of Uzbekistan dated February 7, 2017 N UP-4947 "On the action strategy for further development of the Republic of Uzbekistan," Resolution of the President of the Republic of Uzbekistan "On Establishment of the State Committee on Investments of the Republic of Uzbekistan" dated March 31, 2017, No-4996, August 


\begin{tabular}{|c|c|c|c|c|c|c|}
\hline \multirow{4}{*}{ Impact Factor: } & ISRA (India) & $=4.971$ & SIS (USA) & $=0.912$ & ICV (Poland) & $=6.630$ \\
\hline & ISI (Dubai, UAE & $=0.829$ & РИНЦ (Russia & $=0.126$ & PIF (India) & $=1.940$ \\
\hline & GIF (Australia) & $=0.564$ & ESJI (KZ) & $=8.716$ & IBI (India) & $=4.260$ \\
\hline & JIF & $=1.500$ & SJIF (Morocce & $=5.667$ & OAJI (USA) & $=0.350$ \\
\hline
\end{tabular}

1, 2018 No. UP-5495 "On measures to radically improve the investment climate in the Republic of Uzbekistan", Resolution of the Cabinet of Ministers of the Republic of Uzbekistan from September 25, 1998 of No. 410 "On measures for organization of activity of investment funds".

Materials And Methods

With the adoption of the decree of the president of the Republic of Uzbekistan № PQ-4335 of May 23, 2019 "on additional measures for the rapid development of the building materials industry", more favorable conditions have been created for local and foreign investors to implement promising projects in the direction of production of imported substitute and export-oriented building materials in the Republic.

In particular, since July 1, 2019 in the implementation of projects, the following benefits were granted:

- The costs of certification of exported products of producers of local building materials shall be paid by the Export Development Agency of the Ministry of investments and foreign trade of the Republic of Uzbekistan in accordance with the calculations based on the agency" Uzstandard";

- The taxation base of business entities shall be reduced for five years to the amount of costs for the construction of Engineering, Communication and transport infrastructure necessary for the development of deposits of non-mineral resources in equal shares, but not more than the amount calculated in accordance with the norms established by the Ministry of energy and transport of the Republic;

- Construction materials that have passed the relevant tests and have been certified in accordance with the established procedure can be used in construction works;
- Information about the type or appearance of man-caused mineral formations, their quantitative and qualitative characteristics, and the technical conditions of their storage shall be provided free of charge to business entities upon their request;

At the expense of the State Fund for Support of Entrepreneurship Development under the Cabinet of Ministers of the Republic of Uzbekistan, the initiator of the project will be repaid a portion of the loan or guarantee for the loan up to 8 billion soms. firstly, to the availability of investment capacity. It consists of natural, labor reserves, as well as production, consumption, financial, innovation, institutional and infrastructural capacities;

secondly, the existing investment conditions in the country are important. These include: general economic, Market, normative-legal, Information and communication, environmental, social, cultural conditions;

thirdly, Investment Risk Factors. They include: political, legal, economic, social, financial, Foreign Economic, criminal and etc. They are opposed to the tasks of using the investment capacity of foreign investors and the favorable advantages of investment conditions.

Currently, with the emergence of new types of construction materials in the global market, much of the domestic market's demand for modern building materials is met through the production of new types of building materials using local raw materials and compounds.

\section{Results}

One of the key factors in achieving these results is the investment in the national economy and the construction materials industry (Table 1).

Table 1. Dynamics of Attracting Domestic and Foreign Investments in the Economy of Uzbekistan for 20122018 (billion/uzs.)

\begin{tabular}{|c|c|c|c|c|c|c|c|c|c|}
\hline \multirow{2}{*}{\multicolumn{2}{|c|}{ Name of the indicators }} & \multirow{3}{*}{$\begin{array}{l}2012 \\
17953\end{array}$} & \multicolumn{6}{|c|}{ Years } & \multirow{3}{*}{$\begin{array}{c}2018 \text { as } \\
\text { compared to } \\
2017, \%\end{array}$} \\
\hline & & & \multirow{2}{*}{$\begin{array}{l}2013 \\
22797\end{array}$} & \multirow{2}{*}{$\begin{array}{r}2014 \\
28694\end{array}$} & \multirow{2}{*}{$\begin{array}{l}2015 \\
35233\end{array}$} & \multirow{2}{*}{$\begin{array}{l}2016 \\
41670\end{array}$} & \multirow{2}{*}{$\begin{array}{l}2017 \\
48083\end{array}$} & \multirow{2}{*}{$\begin{array}{r}2018 \\
68423\end{array}$} & \\
\hline 1 & $\begin{array}{l}\text { Investment in fixed } \\
\text { assets }\end{array}$ & & & & & & & & \\
\hline 2 & $\begin{array}{l}\text { Foreign investments } \\
\text { and loans in fixed } \\
\text { assets }\end{array}$ & 3853 & 4653 & 5532 & 6980 & 8309 & 10611 & 17146 & $161,5 \%$ \\
\hline 3 & $\begin{array}{l}\text { including: direct and } \\
\text { other investments }\end{array}$ & 3215 & 3668 & 4315 & 5489 & 6133 & 7353 & 12768 & $173,6 \%$ \\
\hline
\end{tabular}




\begin{tabular}{|c|c|c|c|c|c|c|}
\hline \multirow{4}{*}{ Impact Factor: } & ISRA (India) & $=4.971$ & SIS (USA) & $=0.912$ & ICV (Poland) & $=6.630$ \\
\hline & ISI (Dubai, UAE & $=0.829$ & РИНЦ (Russia) & $=0.126$ & PIF (India) & $=1.940$ \\
\hline & GIF (Australia) & $=0.564$ & ESJI (KZ) & $=8.716$ & IBI (India) & $=4.260$ \\
\hline & JIF & $=1.500$ & SJIF (Morocco) & $=5.667$ & OAJI (USA) & $=0.350$ \\
\hline
\end{tabular}

\begin{tabular}{|c|c|c|c|c|c|c|c|c|c|}
\hline 4 & $\begin{array}{c}\text { government- } \\
\text { guaranteed } \\
\text { investments }\end{array}$ & 638 & 984 & 1217 & 1490 & 2176 & 3257 & 4378 & $134,4 \%$ \\
\hline 5 & $\begin{array}{c}\text { Investments in fixed } \\
\text { assets in the building } \\
\text { materials industry }\end{array}$ & 317 & 277 & 420 & 808 & 1057 & 932 & 967 & $103,7 \%$ \\
\hline
\end{tabular}

According to the table, in 2018 for the development of the economy of the Republic of Uzbekistan at the expense of all sources of financing were 68,423 billion. or $142.4 \%$ of capital investments in 2017. In this case, the share of foreign investment in 2018 is 17146 billion dollars. or $161.5 \%$ increase compared to 2017, of which Foreign direct investment is \$ 12768 billion in 2018. or $173.6 \%$ to 2017 .

Successful investment in the construction materials industry depends on a large extent on the following factors. Consequently, the structure of the building materials industry should be accompanied by changes in the structure, development and liquidation of unprofitable enterprises, and changes in the specialization of manufacturing companies that are not competitive. This aspect is more important than building new businesses.

Thus, in order to increase the efficiency of investment attraction in the building materials industry, the following tasks should be developed and implemented in the development of programs and measures for structural transformations in the industry:

- increasing the volume and effectiveness of investment projects aimed at the development of network infrastructure;

- achieving economic independence in the construction industry of the Republic through the establishment and development of enterprises producing substitute products by reducing the import of the most important types of building materials and supplies;

- Efficient use of the rich mineral resources available in the country through localization of production, increasing the level and competitiveness of the products;

- expansion of export potential of the republic, achievement of positive balance of payments in foreign economic relations;

- Efficient use of resources (natural, material, financial, etc.) in the building materials industry. These include the rational employment of labor resources, the introduction of new labor management technologies, and the increasing use of modern management and marketing techniques in management.

\section{Conclusion}

In order to ensure the competitiveness of the products in the construction materials industry, deepening the processes of restructuring, modernization and diversification should become an important priority. Investments are needed to solve these problems.

In general, an important issue related to attracting investments is not to prioritize the distribution of investment, whether domestic or foreign, but for the allocation and placement of the needs of our economy and their efficiency.

\section{References:}

1. (2018). Decree of the President of the Republic of Uzbekistan dated January 22, 2018 NF-5308 "On the State Program on Implementation of the Strategy of Action on the five priority directions of development of the Republic of Uzbekistan in the" Year of active entrepreneurship, support of innovative ideas and technologies ".

2. (2017). Decree of the President of the Republic of Uzbekistan dated February 7, 2017
"On the strategy of further development of the Republic of Uzbekistan".

3. (2018). Address of the President of the Republic of Uzbekistan to the Oliy Majlis December 28, 2018 //xs.uz/uzkr/post/ozbekiston-respublikasiprezidenti-shavkat-mirziyoevning-olijmazhlisga-murozhaatnomasi.

4. Nurimbetov, R.I., \& Matyawakubov, A.D. (2017). Trends in the Construction Materials 


\begin{tabular}{|c|c|c|c|c|c|c|}
\hline \multirow{4}{*}{ Impact Factor: } & ISRA (India) & $=4.971$ & SIS (USA) & $=0.912$ & ICV (Poland) & $=6.630$ \\
\hline & ISI (Dubai, UAE & $=0.829$ & РИНЦ (Russia & $=0.126$ & PIF (India) & $=1.940$ \\
\hline & GIF (Australia) & $=0.564$ & ESJI (KZ) & $=8.716$ & IBI (India) & $=4.260$ \\
\hline & JIF & $=1.500$ & SJIF (Morocec & $=5.667$ & OAJI (USA) & $=0.350$ \\
\hline
\end{tabular}

Industry in Uzbekistan. Construction and Architecture of Uzbekistan, Issue 1-2, pp. 37-42.

5. Teshabaev, A. (2006). Modern enterprise management. (p.300). Tashkent: Science.

6. Topychkanov, D.E. (2004). Features of corporate property management in foreign countries of the post-industrial type. Property and market, No. 3, p.9.

7. (n.d.). Retrieved from www.Mininnovation.uz

8. (n.d.). Retrieved from www.uza.uz

9. (n.d.). Retrieved from www.strategy.uz

10. (n.d.). Retrieved from www.economy.uz 